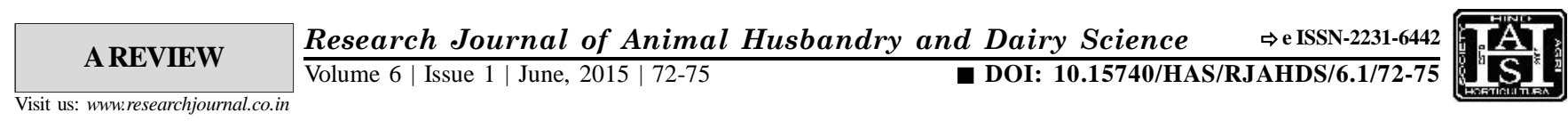

\title{
Development of fruit based yoghurt
}

\author{
J.N. KHEDKAR, D.M. CHOUDHARI, B.K. PAWAR AND V.S. KADAM
}

\begin{abstract}
Yoghurt is a co-agulated milk product obtained by lactic acid fermentation through the action of starter organisms i.e. Lactobacillus bulgaricus and Streptococcus thermophillus from milk and milk products (Pasteurized or concentrated milk) with or without optional additions (Milk powder, skim milk powder, whey powder etc.) The micro-organism in the final product must be viable and abundant $\left(10^{8-10}\right)$. In conclusion : Additions of fruits in yoghurt relish the product and add nutritional and therapeutic benefits to the consumers. The yoghurt with fruit juice/pulp combinations seems to hold good promises in the manufacture of value added nutritious beverages. Such beverages have been found to be highly acceptable as refreshing drink.
\end{abstract}

KEY WORDS : Milk, Yoghurt, Fruits

HOW TO CITE THIS PAPER : Khedkar, J.N., Choudhari, D.M., Pawar, B.K. and Kadam, V.S. (2015). Development of fruit based yoghurt. Res. J. Animal Hus. \& Dairy Sci., 6(1) : 72-75.

\section{MEMBERS OF RESEARCH FORUM}

Address for correspondence :

B.K. Pawar, Department of Animal Science and Dairy Science, College of Agriculture, PUNE (M.S.) INDIA

Associated Authors':

J.N. Khedkar and V.S. Kadam, Department of Animal Science and Dairy Science, Post Graudate Institute, Mahatma Phule Krishi Vidyapeeth, Rahuri, AHMEDNAGAR (M.S.) INDIA

D.M. Choudhari, Shramshakti College of Agriculture, Maldad, Sangamner, AHMEDNAGAR (M.S.) INDIA 